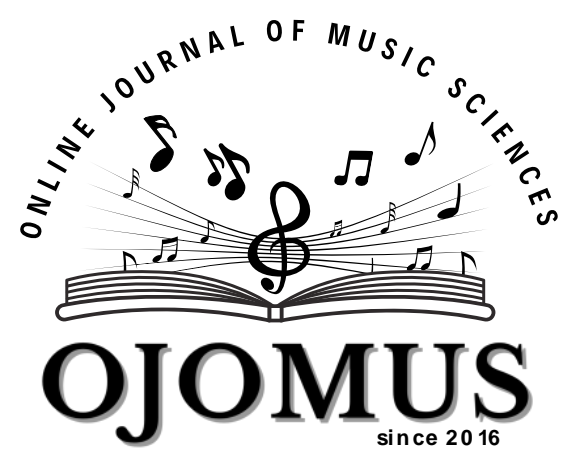

\title{
ONLINE JOURNAL OF MUSIC SCIENCE
}

\author{
Çevrimiçi Müzik Bilimleri Dergisi
}

\section{SALIH ZEKI BEY'IN “MEBHÂS-I SAVT” ADLI ESERİ}

\section{SALIH ZEKI BEY'S WORK NAMED MATTER OF SOUND ATIF/CITATION}

Bașar, A. (2021). Salih Zeki Bey'in "Mebhâs-ı Savt" adlı eseri. Online Journal Of Music Sciences, 6(1), 61-80. https://doi.org/10.31811/ojomus.939003

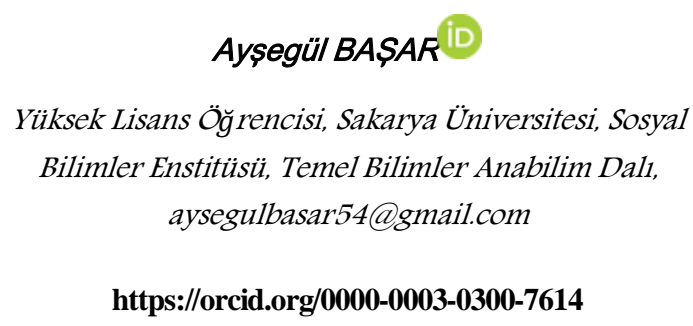

https://orcid.org/0000-0003-0300-7614
Cilt/Volume: 6

Sayı/lssue: 1

Haziran/June 2021

Araștırma Makalesi/Research Article Geliș Tarihi/Received: 19.05.2021

Kabul Tarihi/Accepted: 26.06.2021

Yayım Tarihi/Published: 30.06.2021

\section{d.}

https://doi.org/10.31811/ojomus.939003

"Salih Zeki Bey'in Hikmet-i Tabiìyye-i Umûmiyyeden Mebhâs-ı Savt" isimli eseriyle ilgili yapılan yüksek lisans tezinden üretilmiștir. 
Öz

Salih Zeki Bey Osmanlı Devleti'nin son dönemlerinde yetișmiș matematik ve fizik bilginidir. Yaptığı çalıșmalarla Türk bilim tarihi yazıcılığının öncü ismi olarak kabul edilmektedir. Çeșitli kurumlarda memuriyet ve Darülfünûn'da uzun yıllar hoca olarak görev yapmıș ve pek çok eser kaleme almıștır. Bu eserlerinden biri de TTK Kütüphanesi'nin "A005920" numaralı dijital kaynağından ulaștığımız 1910 basımlı "Mebhâs-ı Savt" adlı eseridir. Eser Osmanlı'da ses fiziği alanında yayımlanmıș ilk eser olması bakımından önem tașımaktadır. Eser 4 ana bölümden olușmaktadır ve ayrıca müellif "Mûsikî Sesleri” bahsine de yer vermiștir. Bu çalıșmanın amacı, adı geçen “Mûsikî Sesleri”nin incelenip, Salih Zeki Bey’in bilimsel anlamda mûsikîmize katkılarının görülmesidir. Bu çalıșmada tarihsel araștırma yöntemi kullanılmıș ve veriler döküman inceleme tekniği ile toplanmıștır. Bazı perde isimlerinin günümüzdekilerden farklı olduğu tespit edilmiștir. Ayrıca makam dizilerinin, günümüz nazariyesinde kullanılan dizilerden birtakım farklılıkları olduğu görülmüștür.

Anahtar Kelimeler: Ses Fiziği, Mebhâs-ı Savt, Mûsikî Sesleri, Salih Zeki

\begin{abstract}
Salih Zeki Bey was a mathematician and physicist who had lived in last era of Ottoman Empire. He is well accepted as a leading name of science histography due to the breakthroughs he had contributed in different branches of science. He had worked in various institutes, been a teacher in Darülfünun for years and written many important works. One of these works is "Mebhâs-ı Savt" which was published in 1910 that we had access in TTK Library digital source number "A005920". The work is important due to its quality as the first publishing on the subject of acoustics in Ottoman Era. The work has four main parts, besides the author had written a part on the subject "Sounds of Music", as well. The purpose of this study is to inspect the part "Sounds of Music" of the work and present Salih Zeki Bey's scientific contributions to our music. Historical research method has been used in the study and the data has been collected with document review technique. Is has been found that some of the tonic key names were different than the ones that we currently use. It has been also seen that some of the tonality cadences show some differences from the ones that are currently used in music theory.
\end{abstract}

Keywords: Acoustics, Mebhâs-ı Savt, Sounds of Music, Salih Zeki 


\section{GiRiș}

Mûsikî kendi içinde konusu, kuralları ve yöntemi olan bir bilim dalıdır. Fizik, matematik, edebiyat ve tarih gibi bilim dallarıyla iç içedir. Her toplum için farklı bir kimlik kazanan mûsikî kültürünün gelișimi de her toplumda farklılıklar gösterir.

Türk mûsikîsi tarihi, geniș bir coğrafyayı ve uzun bir zamanı kapsar. Geçmișten günümüze Türk mûsikîsinde hem önemli hanende, sazende, bestekâr ve müzikologlar yetișmiș hem de Türk mûsikîsini bize bilimsel bir șekilde tanıtan nazarî sistemler gelișmiștir.

13.yüzyılda Safiyüddin Urmevi ile bașlayan ve "Sistemci Okul" olarak adlandırılan sistem on yedili ses sistemini esas alır. Bu sistem 15. Yüzyılın bir kısmını kapsayacak șekilde devam etmiștir (Köprülü, 2018, s.265). Sistemci okuldan sonra Ladikli Mehmet, Cemișgezekli Șükrullah ve Molla Câmî gibi isimlerin çalıșmaları olmuștur.

Aradan geçen uzun bir zamandan sonra Rauf Yekta Bey'in kurduğu sistem karșımıza çıkar. Bu sistem 24 perdeli ses sistemidir. Çalıșmalarıyla mûsikî nazariyatı alanının fizik temellerini atan Yekta'nın sisteminde, ana dizi olarak Yegâh dizisi kabul edilmiștir.

Töre- Karadeniz sistemi olarak bilinen sistemin ana çizgileri Abdülkadir Töre tarafından ortaya koyulmuș ve daha sonra öğrencisi Ekrem Karadeniz tarafından derlenmiștir. Bu sistem 41 aralıklı ses düzenine göre kurulmuștur ve Sent sistemi yerine Türk sent usûlü adı verilen yeni hesap sistemi kullanılmıștır.

Arel- Ezgi sistemi, günümüzde de kullanılan, 24 perdeye dayalı sistemdir. Bu sistemde Rauf Yekta Bey sisteminden farklı olarak Çargâh dizisi esas alınmıștır

Rauf Yekta Bey Osmanlı mûsikîsinin ilmi esaslarının tespitinde önemli rol oynamıștır. Yaptığı çalıșmalarda, müzikolojinin ayrılmaz bir parçası olduğuna inandığı ses fiziği konularında, ünlü fizik bilgini Salih Zeki Bey'den yararlanmıștır (Öncel, 2014, s.48). Salih Zeki Bey, Yekta'nın araștırmalarına ilgi göstermiș ve konuyla ilgili Batıdaki çağdaș bilgiyi Osmanlı dünyasına aktaran ilk fizikçi olmuștur (Öztürk, 2020, s.187). Ayrıca çalıșmalarıyla Türk bilim tarihi yazıcılığının öncüsü sayılmaktadır.

Osmanlı'nın son dönemlerinde yetișmiș olan Salih Zeki Bey'in önemli eserleri vardır. Bu eserlerden biri de Darülfünûn'da hocalık yaptığı dönemde, derslerde okutulması için, hazırladığı "Hikmet-i Tabîiyye-i Umûmiyye'den Mebhâs- Savt" adlı eseridir. Bu eser Osmanlı'da ses fiziği alanında yayımlanmıș ilk eserdir. 
Ayşegül BAŞAR

Araștırmamızın konusu Salih Zeki Bey'İn "Hikmet-i Tabîiyye-i Umûmiyye'den "Mebhâs-ı Savt" adlı eseridir. "Mebhâs-ı Savt'taki "Mûsikî Sesleri" bahsi nasıldır?" sorusu problem cümlesi olarak belirlenmiștir.

\subsection{Araştırmanın Amacı}

Bu araștırmanın amacı; "Mebhâs-ı Savt" adlı eserin genel içeriğinin tanınması ve "Mûsikî Sesleri'nin incelenip Salih Zeki Bey'in bilimsel anlamda mûsikîmize katkılarının görülmesidir. Bu amaç ıșığında așağıdaki alt problemlere cevap aranacaktır.

1- Mebhâs-ı Savt'ın genel özellikleri nelerdir?

2- Mebhâs-ı Savt'taki mûsikî sesleri ve mûsikî aralıkları nasıldır?

3- Mebhâs-ı Savt'ta Batı mûsikîsi bahsi nasıldır?

4- Mebhâs-ı Savt'ta Doğu mûsikîsi bahsi nasıldır?

\subsection{Araștırmanın Önemi}

Mebhâs-ı Savt Osmanlı'da modern akustikle ilgili yayımlanmıș ilk eserdir. Bu çalıșma Salih Zeki Bey'in Mebhâs-ı Savt adlı eserinin gün yüzüne çıkarılması ve Osmanlı mûsikîsinin bilimsel esaslarına olan katkılarının görülmesi açısından önem tașımaktadır.

\section{YÖNTEM}

Bu çalıșmada kullanılan yöntem nitel araștırma yöntemlerinden, tarihsel araștırma yöntemidir. Tarîhsel araștırma yöntemi: "Dönemin dökümanları incelenerek ya da o zamanda yașamıș kișilerle görüșmeler yapılarak odaklanılan problemle ilgili olarak "Geçmiște ne oldu?" sorusuna cevap arar" (Büyüköztürk, Akgün, Demirel, Karadeniz ve Kılıç, 2019, s.21). Bu yöntemden hareketle elde edilen veriler yorumlanmıș ve alt problemlere göre bulgular bölümüne yerleștirilmiștir. Evrenin tamamına ulașılan çalıșmanın örneklemi "Mûsikî Sesleri” dir.

\section{BULGULAR}

\section{MEBHÂS-I SAVT'IN GENEL ÖZELLIKLERI:}

\section{Eserin İsmi}

"Mebhâs" kelimesi, Arapça çoğul isim olarak; bir șeyin arandığı yer; arama araștırma yeri; bâb, fasıl; "logie": ilim, bilim sözünün karșlığıdır (Devellioğlu, 2006, s.592). Arapça tekil isim olan "Savt" ise; ses, sadâ; ağırma, haykırma, çığlık gibi anlamlara gelir (Devellioğlu, 2006, s.922). Eserin konusu düșünüldüğünde, Mebhâs-ı Savt Arapça bir isim tamlaması olarak "Ses Bahisleri","Ses Bilgisi", "Fonetik" gibi șekillerde tercüme edilebilir. 
Yazım Tarihi:

Matbaâyı Âmire 1326/1910 160 s.

Esere TTK Kütüphanesi'nin “A005920” numaralı dijital kaynağından ulașılmıștır.

Konusu ve lçeriği

Mebhâs-ı Savt döneminde modern akustik adına yazılmıș ilk kitaptır. Salih Zeki Bey bu eserinin Darülfünûn'da verdiği fizik derslerinin özeti olduğunu eserin önsözünde belirtmiștir. Eser içinde "Mûsikî Sesleri" bölümü Salih Zeki Bey'in mûsikî nazariyemize yaptığı katkıları göstermesi açısından önem tașımaktadır. Eser, giriș ve 4 ana bölümden olușmaktadır:

Giriș: Bu bölümde "Mûsikî sesleri" bașlığı altında yer alan konular așağıdaki gibidir:

-Ses: Șiddet, Yükseklik, Çınlama, - Mûsikî aralıkları, -Melodi , Armoni, -Batı mûsikîsi, - Uyumlu ve Uyumsuz aralıklar, -Majör gam veya Batlamyus gamı,- Minör gam, -Pisagor gamı: Diyez, Bemol, -Tampere gam, -Âhenk - Tabîi gam, -Armonik Sesler, -Șark mûsikîsi, -Dizi (Mıstar), -Makâmât gibi konulardan bahsedilmektedir.

Birinci Bölüm: Bu bölümde "Titreșim hareketinin yayılması ve yankılanması" bașlığı altında yer alan konular așağıdaki gibidir:

-Titreșim hareketinin muâdele-i tefâzuliyesi (muâdele:Denklem, tefâzulî: İki rakam arasında miktarca olan farktan doğan nisbet), muâdele-i tefâzuliyenin tamamlanması, -Titreșim hareketinin devri, safhası - tenbîh, -Titreșim hareketinin șiddeti , enine ve boyuna titreșim: Boyuna titreșimin elastik bir silindir aracılığıyla yayılması, -Yayılma olayının muâdele-i tefâzuliyesi - muâdele-i tefâzuliyenin tamamlanması, -Dalgalanma hareketi, toplanmıș dalga, yayılmıș dalga-dalga boyu, dalga boyu ile titreșim devri arasındaki münâsebet, -Boyuna titreșimin sınırsız bir silindir içinde yayılması ,- Enine titreșim, -Sesin yayılma hızı, gazlarda sesin yayılma hızı, -Newton nazariyesi, -Sıvılarda sesin hızı, Katılarda sesin hızı - Tenbih gibi konulardan bahsedilmektedir.

İkinci Bölüm: Bu bölümde "Titreșim hareketlerinin tedâhülü” bașlığı altında yer alan konular așağıdaki gibidir:

-Aynı devre tâbi iki titreșim hareketinin birleștirilmesi, -Tecrübelerin araștırılması, Titreșim hareketinin birleștirilmesi için Ferenli esası, Zıt devir iki titreșim hareketinin birleștirilmesi,- Darban hâdisesi ve açıklaması- seslerin salıverilmiș yüksekliklerinin tayini,- Bileșik sesler - bileșik seslerin armoniye tatbiki, - İki dik titreșim hareketinin terkibi - özel hallere tatbik, - Leysajonun usûl tahkiki gibi konuları içermektedir.

Üçüncü Bölüm: Bu bölümde "Ses çıkaran borular" bașlığı altında yer alan konular așağıdaki gibidir: 
Ayşegül BAŞAR

- Sada Boruları, - Bernolli nazariyesi: Kapalı sadâ boruları, kanunları, düğüm ve batın (karın, iç) noktaları, Açık sadâ boruları,kuralları;düğüm ve batın noktaları, -Bir tarafı kapalı sınırlı silindirin ses karıșımları- tecrübelerin araștırılması - tecrübe ile nazariye arasındaki zıtlık, -Postun nazariyyesi, -Hopkins ve (Ket) in doğrulamaları, sabit miktarın tayini - Tenbih - Sesin hızının borular vasıtâsıyla tayini gibi konulardan bahsedilmektedir.

Dördüncü Bölüm: Bu bölümde “ Tellerin titreșimleri” bașlığı altında yer alan konular așağıdaki gibidir:

-Ses çıkaran telli aletler, -Tellerin titreșimleri, -Enine titreșen teller ve muâdele-i tefâzuliyesi muâdele-i tefâzuliyenin tamamlanması - özel haller, - Forye davası, -Taylor kuralları, -Tellerin titreșim kanunları - sür'at-ı ibtidâiye (bașlama hızı)siz yer değiștirmesi, -Tenbih, -Yong kanunu, - ince çubukları -Boyuna titreșim - tellerin boyuna titreșimleri- çubukların enine titreșimleri ve denklem nisbeti - bu denkleme uyan hareket-i raksiye, -Birinci durum: Çubuğun her iki ucunun serbest bırakılması, -İkinci durum: Çubuğun uclarının sâbit kalması, -Üçüncü durum: Çubuğun bir ucunun serbest ve bir ucunun sabit olması, -Dördüncü durum: Bir ucunun serbest ve diğerinin dayandırılması, -Beșinci durum: Bir ucunun sabit ve diğerinin dayandırılması, -Altıncı durum: İki ucun birden dayandırıması, -Zarların titreșimleri, -Levhaların titreșimleri konularını içermektedir.

\section{MÛSIKİ SESLERI (ESVÂT-I MÛSIKIYYE) VE MÛSIKİ ARALIKLARI (FÂSILA-I MÛSIKIYYE)}

Kulağımızı uyaran ve beynimizde duyumlara yol açan etkiler sesi olușturur (Zeren, 2003, s.11). Salih Zeki Bey sesin tarifini șöyle yapmaktadır: Fizik bilimi açısından ses, bir cisimde meydana getirilen ve kulağa kadar intikal eden bir titreșim hareketidir (Zeki, 1910, s.5).

Müellif titreșim hareketinin, "güç (genișlik)", "süre" ve "muharrik" (hareket getiren) açısından, müzikte üç niteliğe uyduğunu söylemiștir. Bunlar; "șiddet", "yükseklik veya perde" ve "çınlamadır" (Zeki, 1910, s.5)

Kulağa gelen her titreșim mutlaka bir ses hissi vermez çünkü bir sesin kulak vâsıtasıyla ișitilmesi için o sesin ne çok pest ne de tiz olmaması gerekir (Zeki, 1910, s.6). Müellif bu seslerin, geçmiș tecrübelere göre, ișitilmesi mümkün olan seslerin en pestinin sâniyede 16 tam titreșimden meydana geldiğini ve en tizinin de 38000 tam titreșimden meydana geldiğini söylemiș ve bu sesleri "özel sesler" olarak nitelendirmiștir. Bu oranların günümüzde 20 ile 20000 olarak kabul edildiği görülmüștür. (Özkan, 1994, s.29). Kulak vâsıtasıyla hissedilen seslerin hepsi mûsikîde kullanılmaz. Mûsikîde kullanılan sesler titreșim sayıları saniyede 30 ile 4000 arasında bulunanlardır (Zeki, 1910, s.6)

Frekans bir cismin bir saniyedeki titreșim sayısıdır, frekans arttıkça ses incelir, azaldıkça kalınlașır (Özkan, 1994, s.53). Aralık ise iki ses arasındaki frekans farkıdır. Müellif genel olarak bir sesin bir saniyedeki titreșim hareketiyle değerlendirildiğini, o nedenle iki ses arasındaki "aralık"ın da bu 
Salih Zeki Bey'in "Mebhâs-1 Savt" adlı eseri

titreșim sayıları arasındaki bağ ile ifade edilmesi gerektiğini söylemiștir. Bu iki sesten ince olanının kalın olanına bağlı olması esası kabul edilmiștir (Zeki, 1910, s.7). "Ses aralığı, tiz sesin pest sesinkine oranıyla yani bağıl frekansıyla anlatıır. Bir aralığı olușturan seslerin mutlak frekansları değișebilir. Ama aralarındaki oran değișmiyorsa hep aynı aralık olușur ve dolayısıyla aynı müzik duygusu algılanır. Aralığı olușturan seslerden birinin frekansını ve aralığın bağıl frekansını biliyorsak öbür sesin frekansını kolayca bulabiliriz" (Zeren, 2010, s.295-296).

Mûsıkîde kullanılan ve "mûsikî aralıkları" denilen aralıkların iki görüș üzerine olduğunu söyleyen müellif bunları așağıdaki șekilde tanımlamıștır (Zeki, 1910, s.7):

1) Melodi: İki sesin birbirini takipteki uyumunun kulağa hoș gelmesidir.

2) Armoni: İki veya daha çok sesin bir anda ortaya çıkıșının kulakta güzel bir tesir olușturmasıdır.

Doğu mûsikîsinin sadece melodiden ibâret olduğunu söyleyen müellif, batı mûsikîsinin ise melodi ile berâber armoniden meydana geldiğini söylemiștir (Zeki, 1910, s.7).

\section{Uyumlu Aralıklar (Fâsılât-ı Mülâyime) ve Uyumsuz Aralıklar (Gayrı Mülâyime):}

Gerek melodi ve gerek armoni için olsun, kulak daima titreșim sayıları arasından mümkün mertebe basit olan sesleri seçer (Zeki, 1910, s.7). Sesler arasındaki bu bağlılık derecesi ne kadar basit olur ise bunların birbirini takibi ve birleșmesi kulağa o derece uyumlu ve ne kadar karmakarıșık bulunur ise kulağa o derece uyumsuz gelir (Zeki, 1910, s.7).

İyi oranlar (uygun oranlar) olarak adlandırılan niseb-i basîtenin ${ }^{1}$ birincisi 1/1' dir ve bu aralığa tek ses (hâdiye) adı verilmiștir. Bundan sonra 2/1 oranı gelir ve buna da oktav (sâmine) denilmiștir (Zeki, 1910, s.7)

Müellif, gerek melodi gerek armoni açısından, kulağa hoș gelen mûsikî aralıklarını așağıda olduğu gibi göstermiștir (Zeki, 1910, s.7):

$\frac{1}{1}$ Tek ses (Hâdiye) (Unisson)

$\frac{5}{4}$ Üçlü majör (Salise-i kübrâ) ( Tierce majeure)

$\frac{6}{5}$ Üçlü minör (Sâlise-i sugrâ) ( Tierce mineure)

\footnotetext{
${ }^{1}$ Bkz. Issmail Hakkı Özkan, age, Ötüken Neșriyat, Istanbul 1994, Pan Yayıncılık, İstanbul, 2003, s. 73; Yılmaz Öztuna, Büyük Türk Mûsikîsi Ansiklopedisi 2, Kültür Baknlığı Yay., Ankara, 1990 s. 131
} 
Ayşegül BAŞAR

$\frac{4}{3}$ Dörtlü (Râbia) ( Quatre)

$\frac{3}{2}$ Beșli (Hâmise) (Quinte)

$\frac{5}{3}$ Altılı majör (Sâdise-i kübrâ) (Sixte majeure)

$\frac{8}{5} \quad$ Altılı minör (Sâdise-i sugrâ) (Sixte mineure)

$\frac{2}{1}$ Sekizli (Sâmine) ( Octave )

Batı mûsikîsinde tek ses ile sekizli arasındaki uyumlu aralıklardan bașka așağıda olduğu gibi "uyumsuz aralıklar" da kullanılır diyen müellif bu aralıkları așağıdaki șekilde göstermiștir (Zeki,1910,s.8):

$\frac{9}{8}$ íkili majör (Sâniye-i kübrâ / Seconde majeure)

$\frac{10}{9}$ İkili minör (Sâniye-i sugrâ / ( Seconde mineure)

$\frac{16}{15}$ Yarım ikili majör (Nısf-ı sâniye-i kübrâ / Demi-Seconde majör )

$\frac{15}{8}$ Yedili majör (Sâbia-i kübrâ / Septiéme majeure)

$\frac{9}{5}$ Yedili minör (Sâbia-i sugrâ / Septiéme mineure

Mûsikîde uyumsuz aralıklara bir lüzum varsa o da uyumlu aralıklar ile zıtlık ve bunların daha tatminkâr ișitilmesi için bir zemin olușturmalarıdır (Zeki, 1910, s.8).

\section{BATI MÛSIKÎSI}

Batı müziği tonalite sistemi içerisinde, yedi temel sesli gamı temel almıș, ancak tonal müzikte gam majör ve gam minör olmak üzere düzenlemiștir (Tarkum, 2017, s.32). Bu seslerin olușturduğu bir sekizli Batı müziğinde birbirine eșit 12 eșit parçaya bölünür (Darbaz, 1973, s.63).

Majör Gam-Batlamyus Gamı: Batı mûsıkîsi'nde kullanılan ve "gam majör" (Gamme majeure) veya "Batlamyus gamı" (Gamme de Ptoléméé) ismiyle bilinen gamı olușturan perdelerin, en pest olanının tam titreșim sayısı bir sayılmaktadır (Zeki, 1910, s.8). 
Majör gamına genellikle bir dörtlü ile bir beșliden olușmuș gözüyle bakılabileceğini söyleyen müellif, bu gamda "sol" notasının, "asıl ses" (savt-ı aslî) denilen "do" notasına nazaran bir beșli kadar tiz olduğunu, ikinci "do" notasının da "fa" notasından bir beșli kadar tiz olduğunu söylemiștir. $\frac{9}{8}$ aralığına "ton majör" (Ton majeur)

$\frac{10}{9}$ aralığına "ton minör" (Ton mineur)

$\frac{16}{15}$ aralığına "yarım ton majör" (Demi-Ton majeur) adı verilir (Zeki, 1910, s.9).

Minör Gam: Batı mûsıkîșinâslarının bir ikinci gam daha kullandıklarını söyleyen müellif, bu gamda büyük üçlü majör, altılı majör ve yedili majör aralıkları küçükleriyle değiștirilmiș olduğundan, bu gamın "gam minör" (Gamme mineure) adıyla bilindiğini söylemiștir (Zeki, 1910, s.11)

Pisagor Gamı: Avrupa'da bazı mûsıkî üstatları arasında kullanıımıș bir gam daha vardır diyen müellif bunun "Pisagor gamı" (Gamme de Pythagore) adıyla anıldığını söylemiștir.

Pisagor gamının ikili aralığı, armoni gamının ikili majörüne eșittir fakat yarım ikili olan 256/243 aralığı ile asıl ikili aralık arasındaki fark:

$$
\frac{9}{8} \div \frac{256}{243}=\frac{9}{8} \times \frac{243}{256}=\frac{2187}{2048}
$$

den ibaretdir, buna "Apatom" (Apatome) denilir. 256/243 aralığına da "Lima" (Limma) adı verilmiștir (Zeki, 1910, s.14). Bir <apotom> ile bir <lima>3 arasındaki farka gelince o da:

$$
\frac{2187}{2048} \div \frac{206}{243}=\frac{531441}{524288}
$$

miktarına eșittir ve buna bir <Pisagor koması (Comma de Pythagore) denilir. İște Pisagor gamında mevcut olan gerekli bir durumda terk olunabilen en küçük aralık budur (Zeki, 1910, s.14).

2 Fârâbi Yunanca olan lima kelimesini (limma) Arapça "geriye kalan" mânasına gelen "Bakiye" olarak tercüme etmiștir. Bkz. Rauf Yekta, Türk Mûsikîsi, Pan Yay., Istanbul 1986, s. 19

${ }^{3}$ Bugün kendisine yarım kromatik ton adı verilen aralığın eski adı "apotom"dur, diyatonik yarım perde ismi verilen aralığın adı "lima" dır. Bkz. Rauf Yekta, age, s. 35, 36 
Ayşegül BAŞAR

Diyez, Bemol: Her gamda "baș perde" olan asıl ses özel bir ehemmiyete sahiptir. Çünkü bir morso'yu ${ }^{4}$ elde bulunan saza veya okuyacak olan kimsenin sesine uygun gelecek șekilde indirip çıkarabilmek lazımdır (Zeki, 1910, s.41).

"Aristohsen kaidesi" (Réglé d'Aristoxêne) bir notayı diyezlemek ve bemollemek için kullanılan bir kaidedir. Bununla birlikte ünlü mûsikîșinâslardan Delzen (Delezenne) in tesis ettiği bir kâideye göre bir notayı diyezlemek için bundan sonra gelen notanın 15/16 mislini ve bemollemek için de bu notadan evvel gelen notanın 16/15 mislini almak yeterli gelir (Zeki, 1910, s.16).

Armoni gamında araları bir ton ile ayrımıș olan tam perdeler arasına bu sûretle ikișer perde daha ilâve edilir; bunun biri pest olan perdenin diyezi, diğeri tiz olan perdenin bemolüdür. Bundan dolayı bir armoni gamı așağıdaki yedi esas perde ile on diyez ve bemolden mürekkeb bulunur (Zeki, 1910, s16):

Do Dod Reb $\operatorname{Re} \operatorname{Red}$ Mib Mi Fa Fad Solb Sol Sold Lab La Lad Sib Si Do2

Pisagor gamını kullanmayı kabul edenler de ${ }^{5}$ bir notayı diyezlemek ve bemollemek ihtiyacından kurtulmuș değillerdir. Müellif Pisagor gamında bir notayı diyezlemek için o notayı 2187/2048 nisbetinde tizleștirmek ve aksine bemollemek için de 2048/2187 oranında pestleștirmek gerektiğini söylemiștir. (Zeki, 1910, s.17). İște bu diyezler ve bemoller yardımıyladır ki batı mûsikîsinde bir morsoyu "transpoze" etmek eski tabirle yazıldığı perdeden daha tiz veya daha pest perdelerden çalabilmek kolay olmuștur (Zeki, 1910, s.18).

Tampere Gam (Mu'tedil Gam , Gamme Tempérée) : Kullanılan gam hangisi olur ise sâbit perdeli bir müzik aleti mesela piyanoya diyez ve bemollerin hepsini dahil etmek mümkün olamaz (Zeki,1910,s.18). Bundan dolayı diğerine pek yakın bulunan perdeleri birleștirmek ve takrîbi aralıklar ile yetinmek mecburiyeti hâsıl olur. Bu nedenle bir sekizliyi on iki kısma bölmüșlerdir."Mu'tedil gam" (Gamme tempérée) adıyla bilinen bu gamda bir perdenin diyezi ile bundan sonra gelen perdenin bemolü birbirine birleștirilmiștir (Zeki, 1910, s.18).

Ahenk (Accord) - (Te'liff -Uzlaștırma): İki ve daha çok sesin birleșmesinden ortaya çıkan bileșik sese "âhenk" (accord) veya daha doğrusu "te'lîf" (uzlaștırma) denilir (Zeki, 1910, s.20). Burada șunu belirtmek gerekir ki ahenk; herhangi bir sazın perde veya tellerinin belli bir sese göre düzenlemesi anlamını tașımaktadır (Özkan, 1994, s.70). Konumuzu olușturan ahenk ise aslında ahengî aralıktır. Ahengi aralık; iki sesi aynı zamanda ișitilen aralık ki, bir uygu teșkil eder ve tek

4 Morso (Fr:morceau; Alm.: stück; Ing.: piece) müzikal eserleri ifade eden parça anlamına gelmektedir (Aktüze, 2004: 368). Günümüzde çok kullanılmayan bu terim farklı sözlüklerde șu anlamlara gelmektedir; kısa edebi veya müzikal parça. Bkn . Erhan TEKIN, Bando Yarbay Halit Recep Arman, 2020, Rast Müzikoloji dergisi, s. 2445, 2446

5 Galin - Paris - Chevé ekolü. 
Salih Zeki Bey'in "Mebhâs-1 Savt" adlı eseri

sesli mûsikîdeki lahnî aralık mefhumuna uymaz (Öztuna, 1990, s.29). Yine bahsi geçen ahenk için; günümüzde "acor" (uygu) kelimesinin karșılığıdır. Fr. accorder (uyumlamak) fiilinden alınmıș olan akort kelimesi, aynı kökten gelen "aynı anda duyulan birden fazla ses" anlamındaki akor (uygu) terimiyle karıștııılmamalıdır (Tanrıkorur, 2005, s.201).

Müellif üç sesten bileșik bir âhengin kulağa hoș gelmesi için, her birinin asıl sese yani baș perdeye olan oranının basit olmasının yeterli olmadığını; belki bu seslerin birbirine nazaran aralıklarının da basit olmaları gerektiğini söylemiștir. Aksi takdirde bunların birleșmesinden olușan "armoni" kulağa hoș gelmez (Zeki, 1910, s.20). Üç sesten bileșik âhenklerin en mülâyimi DO Mi SOL notalarından olușan âhenktir ve "büyük tam ahenk" (âheng-i tâm-ı kebîr) adıyla anılır. Diğer bir âhenk de DO Mid SOL notalarından meydana gelen "küçük tam ahenk" (âheng-i tâm-ı sagîr)' tir (Zeki, 1910, 21). Batı mûsıkîsinde kullanılan gam "büyük tam ahenk" (âheng-i tâm-ı kebîr)' in tekâmülünden ibarettir; eski tabirle Batlamyus gamının (Zeki, 1910, s.22).

Tabîi Gam: Âdet olunduğu üzere mûsikî seslerinin titreșim sayılarını belli etmek için asıl kabul olunan ses La ${ }_{3}$ ile gösterilen notadır (Zeki, 1910, s.23). On yedinci asırda bu nota Fransa'da saniyede 405 tam titreșim adedinden bileșik olmak üzere tayin edilmiș ise de yavaș yavaș yükselerek 1857 senesinde opera tiyatrosunda titreșim adedi 448'e çıkmıștır. Bunun üzerine Fransa'da 1859 senesinde La 3 notasının 435 tam titreșimden bileșik olmak üzere sabit bir kıymete çıkarılması karar altına alınmıștır (Zeki, 1910, s.23).

İște bu halde La/3 üzerine düzenlenen gama "tabîi gam" (Gamme naturelle) denilir ki titreșim değerleri așağıda olduğu gibidir (Zeki, 1910, s.24).

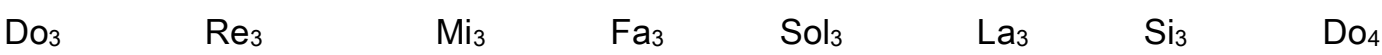

$\begin{array}{llllllll}261 & 625,293 & 25,321 & 384 & 5,391 & 435 & 375,489 & 522\end{array}$

Armonik Sesler (Esvât-ı Müellefe): Titreșim adetleri birincisine göre 1, 2, 3, 4,... tabîî sayıları üzere giden sesler dizisine "esvât-ı müellefe - armonik sesler" (Sons harmoniques) ve titreșim adedi 1 olan "savt-ı aslî- (asıl-temel ses) (Son fondamental)"nin "müellefeleri" (armonikleri) (harmoniques) denilir (Zeki, 1910, s.24). İște majör gamında bu diziyi takip eden sesler sırasıyla yazılacak olursa:

$\begin{array}{cccccccc}\mathrm{Do} 1 & \mathrm{Do}_{2} & \mathrm{Sol}_{2} & \mathrm{Do}_{3} & \mathrm{Mi}_{3} & \mathrm{Sol}_{3} & ! & \mathrm{Do}_{4} \\ 1 & 2 & 3 & 4 & 5 & 6 & 7 & 8\end{array}$

bulunur. Bu dizinin baș taraflarından birbirini takip ederek alınan iki derece, en uygun âhenkleri verir. Meselâ birinci ile ikinci "oktav"ı, ikinci ile üçüncü "beșli”yi, üçüncü ile dördüncü "dörtlü” yü, 
Ayşegül BAŞAR

dördüncü ile beșinci “üçlü”yü olușturur (Zeki, 1910, s.24). Tabîi armoniklerin mûsikîdeki önemi büyüktür. Çünkü mûsikîde kullanılan aralıklar tabîî armoniklerden alınmıștır (Özkan, 1994, s.55)

\section{DOĞU MÛsiKîsi}

\section{Makamlar}

Müellif, bir gamda bulunan perdelerden veya bunlara eșdeğer diğer perdelerden meydana gelen melodilerin bir "makam"dan varsayıldığını ve gamların çeșitli șekilde bileșimleri yönüyle makamların çoğaldığını söylemiștir (Zeki, 1910, s.27). O dönemde kullanılan makam dizilerinin çok çeșitlendiğini ve birçoğunun isminden bașka bir șeyi kalmadığını belirten müellif kullanılan makamların yüzü geçkin olduğunu söylemiștir (Zeki,1910, s.28).

Avrupalılar armoni gamını kolayca diyezlemek ve bemole etmek için majör ton ve minör tonu birbirine denk sayarak bu gamdaki ses aralıklarını ikiye düșürmüșlerdir. Çünkü diyezlemek ve bemole etmek için en çok nizâma tâbi olan gamlar "iki sesli" (Diatonique) gamlardır ki Pisagor gamı veya bizdeki acemașiran dizisi ile ısfahan, nihâvend, mâhur dizisi bunlardandır (Zeki, 1910, s.31).

Gamların çoğalması ve çeșitlenmesi doğu mûsikîsi için büyük bir sakıncadır diyen müellif bunun düzeltilmesinin ise mûsikîșinâslara âit bir vazife olduğunu söylemiștir (Zeki, 1910, s.31).

Lahnî Aralıklar (Eb'âd-ı Lahniye): Doğu mûsikîsinin sırf melodi üzerine kurulu olduğunu söyleyen müellif; bu mûsıkîde kullanılan gamın "mıstar (dizi)" olarak adlandırılığını belirtmiștir. Birbirini takip eden iki mıstar arasını ayıran mûsikî seslerine veya sekizliye "zülküll" denilir (Zeki,1910,s.25). Bir diziyi olușturan perdelerin takip eden aralıklarına ise "eb'âd-ı lahniye" denir. Bu aralıkların isimleri, oranları ve özel ișaretleri așağıda olduğu gibidir (Zeki, 1910, s.25):
$\hookrightarrow:$ Bir tam bakiye aralığı
$\iota^{2}$ : Iki tam bakiye
$\smile^{2} \lambda$ : Iki tam bakiye ile bir eksik bakiye
ح: Eksik bakiye

\begin{tabular}{llc}
\hline \multicolumn{1}{c}{ İsimler } & Sayısal Değerleri & Özel İsaretleri \\
\hline Tanini aralığı & $\frac{9}{8}=1,12507$ & $\omega^{2} \lambda$ \\
\hline Büyük mücenneb aralığı & $\frac{65536}{59049}=1,10985$ & $\omega^{2}$ \\
\hline Küçük mücenneb aralığı & $\frac{2187}{2048}=1,06787$ & $\bullet \lambda$ \\
\hline Tam bakiye aralığı & $\frac{256}{243}=1,05357$ & $\sqcup$ \\
\hline
\end{tabular}


Salih Zeki Bey'in "Mebhâs-1 Savt" adlı eseri

\begin{tabular}{lcc}
\hline Eksik bakiye aralığı & $\frac{531441}{524288}=1,01555$ & \\
\hline Tavîl (uzun) aralığı & $\frac{16777216}{14348907}=1,16930$ & $\iota^{3}$ \\
\hline Atvel (pek uzun) aralığı & $\frac{32}{27}=1,18588$ & $\backsim \lambda^{3}$ \\
\hline
\end{tabular}

Salih Zeki Bey'in "eksik bakiye” olarak gösterdiği sayısal değeri $\frac{531441}{524288}=1,01000$ olan aralık günümüz nazariyesinde "koma” olarak adlandırılmaktadır. "Atvel” aralığı ise artık ikili olarak adlandırılmıștır (Özkan, 1994, s.62). Üç bakiyeden olușan tavil aralığı Arel'de “artık tanini” olarak geçmektedir (Arel, 1932, s.18).

Müellif doğu mûsikîsinden bahsederken bir dizinin aralığı olan sekizli (zülküll)' yi on iki tam bakiye aralığı ile beș eksik bakiye aralığından olușur șeklinde tarif etmiștir (Zeki, 1910, s.25). Eskilerin ise bir sekizliyi bir dörtlü ile bir beșliden meydana gelir șeklinde tarif ettiklerini söyleyip daha sonradan ise bu kanunun muhâfaza olunamadığını söylemiștir (Zeki, 1910, s.25).

Doğu mûsıkîsinde diziler, bu ses aralıkları ile birbirinden ayrılmıș yedi esas perde ve bunlar arasında bulunan ara (tâlî) perdelerden meydana gelir (Zeki,1910,s.25). Müellif bir diziyi olușturan perdelerden her birinin bir özel isimle bilindiğini fakat ara (tâli) perdelerin isimlerinde mûsikîșinâslarca bile anlașmazlık olduğunu söylemiștir. Bu hususu; her ne kadar șimdileri Osmanlı mûsıkîșinâsları perdeleri do, re.... isimleriyle ansalar da bu notaların doğu mûsikîsi perdelerine tamamı tamamına uymadığını göstermek pek kolaydır șeklinde ifade etmiștir (Zeki, 1910, s.26).

Müellif Osmanlı mûsikîsinde kullanılan gamlardan birkaçını așağıdaki șekilde vermiștir (Zeki, 1910, s.26):

\section{Dizi (Mıstar)}

\section{1) Yegâh Dizisi}

\begin{tabular}{llllll}
\hline Perdelerin Yegâh Așiran Irak Rast Dügâh Segâh Çargâh Nevâ \\
İsimleri
\end{tabular}


Ayşegül BAŞAR

$\begin{array}{lllllllll}\text { Sayisal } & 1 & \frac{9}{8} & \frac{8192}{6561} & \frac{4}{3} & \frac{3}{2} & \frac{32768}{19683} & \frac{16}{9} & 2\end{array}$

Oranları

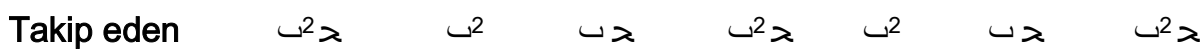

Aralıkları

Yegâh dizisini Rauf Yekta Bey Osmanlı'nın kullandığı tabîî dizi olarak nitelendirmektedir. Rauf Yekta Bey de Yegâh dizisini perde isimleri ve oranlarını Salih Zeki Bey'in yukarıda gösterdiği șekliyle vermiștir (Çergel, 2007, s.62).

Günümüz nazariyesinde ise Yegah makamındaki perdelerin isimleri șu șekildedir: Yegâh'ta Rast dizisi; Yegâh, Hüseyni Așîran, Irak, Rast, Dügâh, Bûselik, Nim Hicaz veya Çargah, Neva. Yerinde Nevâ dizisi: Dügâh, Segâh, Çargâh, Nevâ, Hüseyni, Eviç, Gerdâniye, Acem (Özkan, 1994, s.546).

\section{2) Acemașîran Dizisi}

\begin{tabular}{lcccccccc}
\hline Perdelerin & Acemașîn & Rast & Dügâh & Kürdi & Çargâh & Nevâ & Hüseyni Acem \\
İsimleri & \\
\hline Sayısal & 1 & $\frac{9}{8}$ & $\frac{81}{64}$ & $\frac{4}{3}$ & $\frac{3}{2}$ & $\frac{27}{16}$ & $\frac{243}{128}$ & 2
\end{tabular}

Oranları

\begin{tabular}{|c|c|c|c|c|c|c|c|}
\hline Takip eden & $\varphi^{2} \lambda$ & $\varphi^{2} \lambda$ & $\bullet$ & $\varphi^{2} x$ & $\varphi^{2} \lambda$ & $\varphi^{2} x$ & $\bullet$ \\
\hline Aralıkları & & & & & & & \\
\hline
\end{tabular}

3) Hicaz Dizisi

Perdelerin Dügâh Uzzal Hicaz Neva Hüseyni Acem Gerdaniye Muhayyer

İsimleri

\begin{tabular}{lllllllll}
\hline Sayısal & 1 & $\frac{2187}{2048}$ & $\frac{8192}{6561}$ & $\frac{4}{3}$ & $\frac{3}{2}$ & $\frac{128}{81}$ & $\frac{16}{9}$ & 2
\end{tabular}

Oranları

\begin{tabular}{|c|c|c|c|c|c|c|c|}
\hline Takip eden & $=x$ & $\varphi^{2}$ & $\omega \lambda$ & $\varphi^{2} x$ & $\bullet$ & $\oplus^{2} x$ & $e^{2} x$ \\
\hline Aralıkları & & & & & & & \\
\hline
\end{tabular}

Arel-Ezgi sisteminin getirisi olarak, Hicaz ailesi șeklinde 4 ayrı șekilde incelenen Hicaz makamlarının hepsinde günümüz nazariyesinde, Dügâh perdesinden sonraki perde dik kürdî 
Salih Zeki Bey'in "Mebhâs-1 Savt" adlı eseri

perdesi olarak görünmektedir. Müellif bu perdeyi Uzzal olarak göstermiștir. Uzzal perdesi ile ilgili olarak: Harîrî bin Muhammed'in Kırșehrî Edvar çevirisinde; Kırșehri hicaz makamını tarif ederken, çargâh ile ısfahan arasındaki perdeyi uzzal olarak yazmıștır. Demek ki hicaz ve uzzal birbirlerinin yerine kullanılmaktadır (Doğrusöz, 2007, s.20). Buradaki tarifden de anlașılacağı üzere hicaz ve uzzalın birbirinin yerine ve sonraki dönemde de Hicaz ve Saba'nın birbirinin yerine kullanılmıștır. Fakat müellif Uzzal perdesini Hicaz yerine kullanmamıștır, buradaki Uzzal'ın günümüz nazariyesinde karșılığı Dik Kürdi perdesidir.

\section{4) Uşsak Dizisi}

\begin{tabular}{|c|c|c|c|c|c|c|c|c|}
\hline $\begin{array}{l}\text { Perdelerin } \\
\text { İsimleri }\end{array}$ & Dügâh & Segâh & Çargâh & Neva & Hüseyni & Acem & Gerdaniye & Muhayyer \\
\hline Sayısal & 1 & $\frac{65536}{59049}$ & $\frac{33}{27}$ & $\frac{4}{3}$ & $\frac{3}{2}$ & $\frac{128}{81}$ & $\frac{16}{9}$ & 2 \\
\hline Oranları & & & & & & & & \\
\hline $\begin{array}{l}\text { Takip eden } \\
\text { Aralıkları }\end{array}$ & $\hookrightarrow^{2}$ & $\sqcup x$ & $\hookrightarrow^{2}$ & & $\omega^{2} \lambda$ & 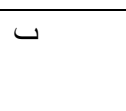 & $\cup^{2} \lambda$ & $\omega^{2} \lambda$ \\
\hline
\end{tabular}

\section{5) Isfahan Dizisi}

Perdelerin Dügâh Bûselik Sabâ Nevâ Hüseyni Acem Gerdaniye Muhayyer
İsimleri

\begin{tabular}{lllllllll}
\hline Sayısal & 1 & $\frac{9}{8}$ & $\frac{81}{64}$ & $\frac{4}{3}$ & $\frac{3}{2}$ & $\frac{128}{81}$ & $\frac{16}{9}$ & 2
\end{tabular}

Oranları

\begin{tabular}{llllllll}
\hline Takip eden & $\uplus^{2} \lambda$ & $\uplus^{2} \lambda$ & $\cup$ & $\uplus^{2} \lambda$ & $\cup$ & $\uplus^{2} \lambda$ & $\uplus^{2} \lambda$ \\
Aralıkları & & & & & & & \\
\hline
\end{tabular}

Isfahan makamı günümüzde basit ve bileșik olmak üzere iki șekildedir. Basit Isfahan makamı dizisinin; Ușșak ve Beyâti makamı dizisine benzer fakat seyri inici-çıkıcıdır, Bileșik Isfahan makamında ise Ușșak ve Beyâti dizisi, yerinde ușșak dörtlüsüne, Nevâ perdesinde bir Bûselik beșlisinin eklenmesinden meydana gelmiștir (Özkan, 1994, s.301). Müellifin verdiği perde isimlerinde Bûselik perdesinden sonra gelen Sabâ perdesi dikkat çekicidir. Sistemci okulun ilk 
Ayşegül BAŞAR

mensuplarının kullandığı ve Dügâhta Isfahan beșlisinde Re koma bemolü olarak gösterilen Uzzal perdesi de bugün kullanılmamaktadır (Kutluğ, 2000, s.341).

6) Sabâ Dizisi

\begin{tabular}{lcccccccc}
\hline Perdelerin & Dügâh & Segâh & Çargâh & Sabâ & Hüseyni Acem & Gerdaniye Muhayyer \\
İsimleri & \\
\hline Sayısal & 1 & $\frac{65536}{59049}$ & $\frac{32}{27}$ & $\frac{81}{64}$ & $\frac{3}{2}$ & $\frac{128}{81}$ & $\frac{16}{9}$ & 2 \\
Oranları & & & & & & & & \\
\end{tabular}

Günümüz nazariyesinde Sabâ makamının perdelerinin isimleri șu șekildedir; Dügâh, Segâh, Çargâh, Hicaz, Dik Hisar, Acem, Gerdâniye, Șehnâz veya Dik Șehnâz, Tiz Çargâh (Özkan, 1994, s.344). Bugün kullandığımız sistemde teoride Hicaz olarak gösterilen perdeyi müellifin verdiği dizide Sabâ perdesi olarak görmekteyiz.

7) Karcığar Dizisi (7)

\begin{tabular}{|c|c|c|c|c|c|c|c|c|}
\hline $\begin{array}{l}\text { Perdelerin } \\
\text { İsimleri }\end{array}$ & Dügâh & Segâh & Çargâh & Nevâ & Hisar & Evc & Gerdaniye & Muhayyer \\
\hline Sayısal & 1 & $\frac{65536}{59049}$ & $\frac{32}{27}$ & $\frac{4}{3}$ & $\frac{729}{512}$ & $\frac{32768}{19683}$ & $\frac{16}{9}$ & 2 \\
\hline
\end{tabular}

Oranları

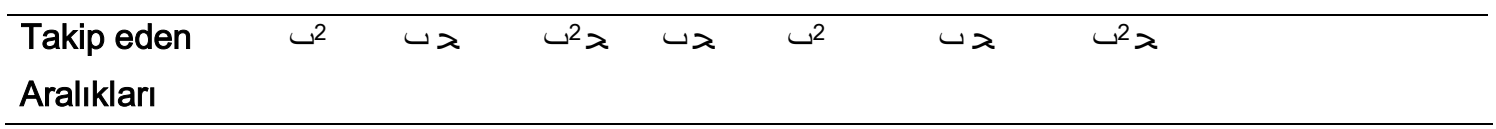

\section{8) Segâh Dizisi}

\begin{tabular}{lrrrr}
\hline Perdelerin Segâh Çargâh Nevâ Hisar Evc Gerdaniye Muhayyer Tiz \\
İsimleri
\end{tabular}


Salih Zeki Bey'in "Mebhâs-1 Savt" adlı eseri

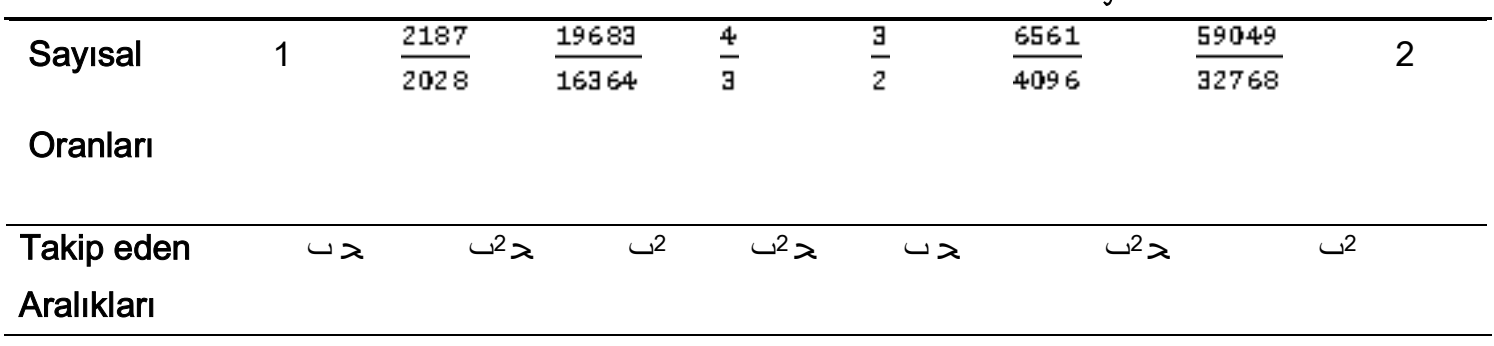

\section{9) Rast Dizisi}

Perdelerin Rast Dügâh Segâh Çargâh Nevâ Hüseyni Evc Gerdaniye
İsimleri

\begin{tabular}{lllllllll}
\hline Sayısal & 1 & $\frac{9}{8}$ & $\frac{8192}{6561}$ & $\frac{4}{3}$ & $\frac{3}{2}$ & $\frac{27}{16}$ & $\frac{4096}{2187}$ & 2
\end{tabular}

Oranları

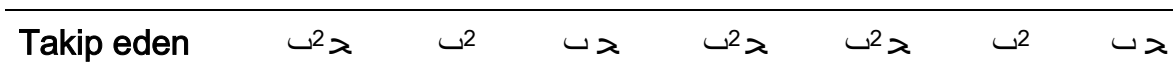

Aralıkları

10) Nihavend Dizisi

\begin{tabular}{|c|c|c|c|c|c|c|c|c|}
\hline $\begin{array}{l}\text { Perdelerin } \\
\text { İsimleri }\end{array}$ & Rast & Dügâh & Kürdi & Çargâh & Nevâ & Beyâti & Acem & Gerdaniye \\
\hline Sayısal & 1 & $\frac{9}{8}$ & $\frac{32}{27}$ & $\frac{4}{3}$ & $\frac{3}{2}$ & $\frac{128}{81}$ & $\frac{16}{9}$ & 2 \\
\hline Oranları & & & & & & & & \\
\hline $\begin{array}{l}\text { Takip eden } \\
\text { Aralıkları }\end{array}$ & $\varphi^{2} \lambda$ & $\bullet$ & $\varphi^{2} \lambda$ & $e^{2} \lambda$ & $\bullet$ & $\varphi^{2} x$ & $e^{2} x$ & \\
\hline
\end{tabular}

Nihavend makamında günümüz nazariyesinde Nevâ perdesinden sonraki perde Nim Hisâr perdesidir. Müellifin verdiği dizide bu perde Beyâti olarak görülmektedir. 
Ayşegül BAŞAR

Müellif kullanılan dizileri yukarıdaki șekilde gösterdikten sonra, bu isimlerin mûsikî üstatlarına göre birbirine uymadığını ve o nedenle de oranların doğru kabul edilmesi gerektiğini söylemiștir (Zeki, 1910, s.27)

\section{SONUÇ VE ÖNERILER}

Salih Zeki Bey matematikçi ve fizikçi olmasının yanı sıra farklı bilim dallarına yaptığı katkılarla Türk bilim tarihinin öncü isimlerinden biri sayılmaktadır. Döneminde mûsikî nazariyesi alanında yapılan çalıșmalara da katkılar sağlamıștır. Mebhâs-ı Savt adlı eseri Salih Zeki Bey'in ses fiziği alanına katkılarının görülmesi bakımından önemli bir eserdir.

Eserde Doğu ve Batı mûsikîsi adına verilen bilgiler, o dönemde kullanılan aralıkların anlașılması açısından ve bilhassa bu konunun uzman bir fizikçi tarafından ele alınmıș olması bakımından da önem tașır.

Eser günümüz sistemiyle 19. yüzyıldaki algı arasında mukayese fırsatı sunmaktadır. Salih Zeki Bey'in Osmanlı'da kullanılan makam dizileri olarak verdiği dizilerin, o dönemin anlayıșıyla sekizli olarak düșünülüp ele alındığı görülmüștür. Günümüzde ise, Arel- Ezgi sisteminde kullanılan șekliyle, dörtlü ve beșliler vardır.

Müellifin verdiği dizilerdeki perde isimleri günümüzdekilerle farklııklar göstermektedir. Bazı perdelerin isimleri belli değildir, bazılarının da ismi hususunda mûsikîșinâslarca fikir ayrıııları vardır.

Bu çalıșma, Osmanlıcadan günümüz Türkçe'sine aktarılmıș olmaması sebebiyle, istifâde edilemeyen eserlerin tanıtılması açısından bir öneri olușturmaktadır.

\section{Araștırmanın Etik Beyanı:}

Bu çalıșmanın tüm hazırlanma süreçlerinde etik kurallara uyulduğunu yazarlar beyan eder. Aksi bir durumun tespiti halinde Online journal of music sciences'ın hiçbir sorumluluğu olmayıp, tüm sorumluluk çalıșmanın yazarına aittir. Ayrıca ULAKBiM TR Dizin 2020 ölçütlerine göre çalıșmada etik kurul onayını gerektiren herhangi bir veri toplamaya ihtiyaç duyulmamıștır.

\section{KAYNAKÇA}

Büyüköztürk, Ș. ve Akgün, Ö. (2019). Bilimsel araștrma yöntemleri (26.Baskı). Pegem Akademi. Çergel, M. (2007). Rauf Yekta Bey'in Ikdam gazetesi'nde neșredilen Türk mûsikîsi konulu makaleleri. (Yüksek Lisans Tezi, Marmara Üniversitesi). space.marmara.edu.tr/handle/11424/11916.

Darbaz, F. (1973). Türk ve Batı müziği. Hüsnitabiat Matbaası 
Devellioğlu, F.(2006). Osmanlıca-Türkçe ansiklopedik Lûgat (23. Baskı). Aydın Kitabevi Yayınları.

Kutluğ, Y. (2000). Türk Musikisi'nde makamlar. Yapı Kredi Yayınları.

Köprülü, G. (2018). 13-15 Yüzyıl orta çağ islam medeniyeti'nde sistemci okul ve Türk mûsıkîsi ilmine katkıları. Tokat Gaziosmanpașa Üniversitesi Ilahiyat Fakültesi Dergisi, 6 (2), 263276. https://dergipark.org.tr/en/download/article-file/596994

Öncel, M. (2014), Türkiye'nin birikimleri-3, müzisyenler. İlke Yayıncılık.

Özkan, İ. (1994). Türk mûsikîsi nazariyatı ve usulleri kudüm velveleleri. Ötüken Neșriyat.

Öztuna, Y. (1990). Büyük Türk mûsikîsi ansiklopedisi 1-2. Kültür Bakanlığı Yayınları.

Öztürk, O. M. (2020). Türk Müziğinde Yekta, Ezgi ve Arel teorilerinin pozitivist inșası: Kısa fakat eleștirel bir tarihçe. Eurasian Journal of Music and Dance, (16), 171-215.

Tanrıkorur, C. (2005), Osmanı dönemi Türk mûsikîsi. Dergâh Yayınları.

Tarkum, E. (2017), Türk Müziği ve batı müziğinin yapısal özellikleri ve çokseslilik açısından incelenmesi. Trakya Üniversitesi Sosyal Bilimler Dergisi, 20 (1), 31-43.

Tekin, E. ( 2020). Bando Yarbay Halit Recep Arman' In Afganistan' da askeri müzik alanında bando çalıșmaları ve besteleri, Rast Müzikoloji Dergisi, 8 (2), 2444-2470.

Yekta, R. (1986). Türk Musikisi. Pan Yayıncılık.

Zeki, S. (1326-1910). Mebhâs-ı Savt. Türk Tarih Kurumu Kütüphanesi (1.8.0.2026) (ttk.gov.tr). Matbaâyı Âmire. İstanbul.

Zeren, A. (2010). Müzik fiziği (5. Baskı). Pan Yayıncılık

\section{EXTENDED ABSTRACT}

\section{Introduction}

Music is a branch of science with its own rules and method. It is intricated with sciences such as physics, mathematics, literature and history. Music has various characteristics in each society that its culture developed within.

The history of Turkish music expands in a wide area and a long time period. From history to our day, many important singers, instrument players, compositors and musicologists have risen in Turkish Music. Also systems of music theory that introduces us Turkish Music in a scientific way have developed in time.

First of these is the school that is known as "Systematical School" and has started in $13^{\text {th }}$ century with Safiyüddin Urmevi, its essential is based on seventeen sound system. This system has continued including a part of $15^{\text {th }}$ Century (Köprülü, 2018, s.265). After the systematic school 
Ayşegül BAŞAR

people such as Ladikli Mehmet, Çemișgezekli Șükrullah ve Molla Camî have worked on the subject.

After a long time, we encounter with Rauf Yekta Bey's system. This system had 24 tonic keys. Yegah cadence is accepted as main cadence in this system that is established by Rauf Yekta Bey who determined the physical essentials of our music theory.

The main characteristics of the system that is widely known as Töre-Karadeniz system has been determined bu Abdülkadir Töre, then the system has been edited by his student Ekrem Karadeniz. This system is established according to 41 gaps sound order and the new calculation system that is called Türk Sent Method has been used insted of Sent system.

Arel-Melody System that the system based on 24 tonic keys and it is still being used. Unlike Rauf Yekta Bey's system the main cadence of this system is Çargah cadence

Rauf Yekta Bey had played a crucial role in determination of scientific basics of Ottoman music and he had built the physical foundation of our music. In his studies that he explains his belief of acoustics being a crucial part of musicology he gives references from Salih Zeki Bey (Öncel, 2014, s.48). Salih Zeki Bey has not only lead Yekta's researches as a science person, he has also been the first physicist who transferred the Western 'modern knowledge' on the subject to the Ottoman world (Öztürk, 2020, s.187). He is also well accepted with his works as the pioneer of the Turkish Science Histography.

Salih Zeki Bey who had lived in last years of Ottoman era has important works. One of these works is "Hikmet-i Tabîiyye-i Umûmiyye'den Mebhâs-ı Savt" that he has written during the period that he was teaching in Darülfünûn to be use as a teaching material. This work is the first study that has been written on acoustics in Ottoman Era.

The subject of our study is Salih Zeki Bey's work named "Hikmet-i Tabîiyye-i Umûmiyye'den "Mebhâs-ı Savt" The problematic question is determined as "How is the "Sounds of Music" topic in "Mebhas-ı Savt"?"

\section{Method}

The method that is used in this study is historical research method from quantitative research methods. Historical research method: "searches an answer to the question "What happened in the past?" involving the focused problem by inspecting the documents from the period of time or interviewing people who lived in that time period. The data we obtained with this method is interpreted and places in findings section according to sub-problems (Büyüköztürk, Akgün, Demirel, Karadeniz ve Kılıç, 2019, p.21).

\section{Findings and Results}


Salih Zeki Bey is accepted as one of the pioneers of Turkish history of science with his works on various branches of science beside mathematics and physics. He contributed to the studies on music theory of his time. His work named Mebhâs-ı Savt is an important work for us to see Salih Zeki Bey's contributions on acoustics.

The knowledge given in the name of Eastern and Western music in the work is important in aspect of understanding the intervals from that time period and especially for it being prepared by a scholar physicist.

The work provides an opportunity of comparison between the system of our day and the perception of 19. Century. It seems that the tonalities that Salih Zeki Bey has been introduced as the tonalities that have been used in Ottoman era were eight series according to the perception of the time. Now we have four and five series in form that are used in Arel-Ezgi system.

The names of the tonic keys that have been introduced by the author are also different than they are now. Some of the names are unknown while there are contradictions between musicians on the names of some tonic keys.

Because this work had not been transcribed from Ottoman Turkish to Modern Turkish, this study is also a reference for works that cannot be used as resources for scientific and academic researches. 